\title{
The inhibition of platelet prothrombinase activity by prostacyclin
}

Citation for published version (APA):

Zwaal, R. F. A., Comfurius, P., Hemker, H. C., \& Beves, E. M. (1984). The inhibition of platelet prothrombinase activity by prostacyclin. Haemostasis, 14(4), 320-324. https://doi.org/10.1159/000215082

Document status and date:

Published: 01/01/1984

DOI:

10.1159/000215082

Document Version:

Other version

\section{Please check the document version of this publication:}

- A submitted manuscript is the version of the article upon submission and before peer-review. There can be important differences between the submitted version and the official published version of record.

People interested in the research are advised to contact the author for the final version of the publication, or visit the DOI to the publisher's website.

- The final author version and the galley proof are versions of the publication after peer review.

- The final published version features the final layout of the paper including the volume, issue and page numbers.

Link to publication

\footnotetext{
General rights rights.

- You may freely distribute the URL identifying the publication in the public portal. please follow below link for the End User Agreement:

www.umlib.nl/taverne-license

Take down policy

If you believe that this document breaches copyright please contact us at:

repository@maastrichtuniversity.nl

providing details and we will investigate your claim.
}

Copyright and moral rights for the publications made accessible in the public portal are retained by the authors and/or other copyright owners and it is a condition of accessing publications that users recognise and abide by the legal requirements associated with these

- Users may download and print one copy of any publication from the public portal for the purpose of private study or research.

- You may not further distribute the material or use it for any profit-making activity or commercial gain

If the publication is distributed under the terms of Article $25 \mathrm{fa}$ of the Dutch Copyright Act, indicated by the "Taverne" license above, 


\title{
The Inhibition of Platelet Prothrombinase Activity by Prostacyclin
}

\author{
R.F.A. Zwaal, P. Comfurius, H.C. Hemker, E.M. Bevers \\ Biomedical Centre, University of Limburg, Maastricht, The Netherlands
}

Key Words. Platelets · Prostacyclin · Prothrombinase

Abstract. Prostacyclin is able to inhibit the development of platelet prothrombinase activity. This inhibition, which also occurs with dibutyryl cAMP, is presumably due to the ability of prostacyclin to prevent the formation of a negatively charged phospholipid surface at the exterior half of the platelet membrane. Generation of this procoagulant surface, as induced by platelet activation with collagen plus thrombin, does not depend on thromboxane $A_{2}$ formation.

\section{Introduction}

In platelet rich plasma the reduction of the recalcification time and Russell's viper venom time induced by kaolin or collagen can be prevented by prostacyclin $[1,2]$. These results have been taken to indicate that prostacyclin inhibits the development of platelet factor 3 activity. This activity is defined as the ability of platelets to shorten the Russell's viper venom-clotting time and therefore refers to the prothrombin converting activity of platelets.

Platelets can provide at least two components for the prothrombinase complex: factor $\mathrm{V}\left(\mathrm{V}_{\mathrm{a}}\right)$ and negatively charged phospholipids [3]. Factor $\mathrm{V}$ appears as a result of the platelet release reaction $[4,5]$ and small amounts of thrombin can convert it to the activated form factor $V_{a}$ [6]. This effect as such can drastically reduce the Russell's viper venom-clotting time $[7,8]$, and is presumably related to the ability of factor $V_{a}$ to create high affinity binding sites for factor $\mathrm{X}_{\mathrm{a}}$ on the platelet outer surface [9-11]. We have previously shown [12, 13] that activation of human platelets, particularly by a mixture of collagen and thrombin, is accompanied with increased exposure of negatively charged phosphatidylserine in the outer leaflet of the plasma membrane, resulting from induced transbilayer movement of phospholipids. Moreover, these platelets have been shown to enhance the conversion of prothrombin to thrombin by a complex of purified coagulation factors $\mathrm{X}_{\mathrm{a}}$ and $\mathrm{V}_{\mathrm{a}}$ in the presence of cal- 
cium. This catalytic activity appeared to be a function of the amount of phosphatidylserine exposed at the outer surface, when the assay is performed with excess of coagulation factors [13]. Furthermore, platelets thus activated cause a drastic reduction of the clotting time in a modified Stypven assay which has been made insensitive to release of factor $\mathrm{V}\left(\mathrm{V}_{\mathrm{a}}\right)$ by the platelets [7].

Since prostacyclin is known to inhibit release of all three granule constituents [14], its anticoagulant property could be explained by preventing release of factor $\mathrm{V}\left(\mathrm{V}_{\mathrm{a}}\right)$. We were interested to see if prostacyclin also interferes with the ability of platelets to generate a procoagulant surface of negatively charged phospholipids.

\section{Materials and Methods}

Prostacyclin was a generous gift of Dr. G. Hornstra, and was dissolved in $1 \mathrm{mM} \mathrm{NaOH}$ at the desired concentration. Aspirin (lysyl-form) and dibutyryl cAMP were from Egic and Sigma, respectively. Collagen type I was obtained from Hormon Chemie, München. In some experiments highly purified collagen type I (generous gift of Prof. J. Caen, Paris) was used, but this produced essentially the same results. Blood coagulation factors $\mathrm{V}_{\mathrm{a}}, \mathrm{X}_{\mathrm{a}}$ and prothrombin were purified as described in Rosing et al. [15]. Thrombin-specific chromogenic substrate $H$ - $D$-phenylalanyl- $L$-pipecolyl-arginine- $p$-nitroanilide dihydro-chloride (S2238) was from AB Kabi Diagnostica, Stockholm.

Blood was drawn from healthy male volunteers and collected in acid-citrate-dextrose (ACD; $0.052 \mathrm{M}$ citric acid/ $0.08 \mathrm{M}$ trisodium citrate $/ 0.183 \mathrm{M}$ glucose; $1 \mathrm{vol}$ of $\mathrm{ACD}$ to $5 \mathrm{vol}$ of blood). Platelet-rich plasma was obtained following centrifugation at $200 \mathrm{~g}$ for $15 \mathrm{~min}$ at room temperature. Platelets were pelleted from platelet-rich plasma at $600 \mathrm{~g}$ for $15 \mathrm{~min}$. The platelet pellet was carefully resuspended in a buffer containing $136 \mathrm{mM} \mathrm{NaCl}, 2.7 \mathrm{mM} \mathrm{KCl}, 2.0 \mathrm{mM}$ $\mathrm{MgCl}_{2}, 25 \mathrm{mM}$ glucose, $10 \mathrm{mM}$ Hepes [4-(2-hydroxyethyl)-1-piperazine ethane sulphonic acid] and $0.05 \%(w / v)$ fatty acid free human serum albumin,
pH 6.6 (Hepes buffer). The platelets were washed twice in this buffer by centrifugation at $600 \mathrm{~g}$ for $15 \mathrm{~min}$. Before each centrifugation 1 vol of $A C D$ was added to $15 \mathrm{vol}$ of platelet suspension. Finally the platelets were resuspended in Hepes buffer, $\mathrm{pH} 7.5$, at a cell count of $10^{7} \mathrm{ml}^{-1}$ (Coulter counter).

Platelet activation by collagen and thrombin and measurement of platelet prothrombin converting activity was carried out essentially as described before [12, 13]. Briefly: $290 \mu \mathrm{l}$ of the platelet suspension was activated in the presence of $15 \mu 175 \mathrm{mM} \mathrm{CaCl} 2$ by $15 \mu \mathrm{l}$ collagen $(200 \mu \mathrm{g} / \mathrm{ml})$ and $5 \mu \mathrm{l}$ thrombin $(125 \mathrm{nM})$ at $37^{\circ} \mathrm{C} .15 \mathrm{~min}$ after activation, $50 \mu \mathrm{l}$ of a freshly prepared mixture containing $30 \mathrm{n} M$ factor $\mathrm{X}_{\mathrm{a}}$ and $60 \mathrm{nM}$ factor $V_{\mathrm{a}}$ was added. 2 min later, the enzymatic reaction was started by addition of $125 \mu \mathrm{l}$ $16 \mu M$ prothrombin. After $1 \mathrm{~min}$ a sample was taken and immediately diluted in a buffer containing $120 \mathrm{mM} \mathrm{NaCl}, 50 \mathrm{mM}$ Tris and $2 \mathrm{mM}$ EDTA ( $\mathrm{pH}$ 7.5) to stop the reaction. The amount of thrombin formed was measured by the change in adsorbance at $405 \mathrm{~nm}$ per unit time produced by the action of thrombin on S2238, and calculated from a calibration curve made with known amounts of active-site-titrated thrombin.

The effect of prostacyclin was measured by incubation of platelets with $5 \mu \mathrm{l}$ prostacyclin (or $5 \mu$ l of vehicle as a control) for $30 \mathrm{~s}$, prior to carrying out the activation procedure by collagen and thrombin. Incubations with dibutyryl cAMP and aspirin were done analogously for $5 \mathrm{~min}$, prior to platelet activation.

Platelet release and aggregation were measured in a Chronolog lumi-aggregometer using firefly luciferinluciferase to measure release of ATP [16]. The extent of ATP released was determined by adding the firefly luciferin-luciferase reagent $5 \mathrm{~min}$ after platelet activation. This was done in order to avoid influence of the ATP reagent on the aggregation behavior.

\section{Results and Discussion}

Addition of prostacyclin to platelets results in a dose-related inhibition of platelet prothrombinase activity as evoked by treatment with collagen plus thrombin (fig. 1, top panel). Half-maximal inhibition was observed at a prostacyclin concentration of 


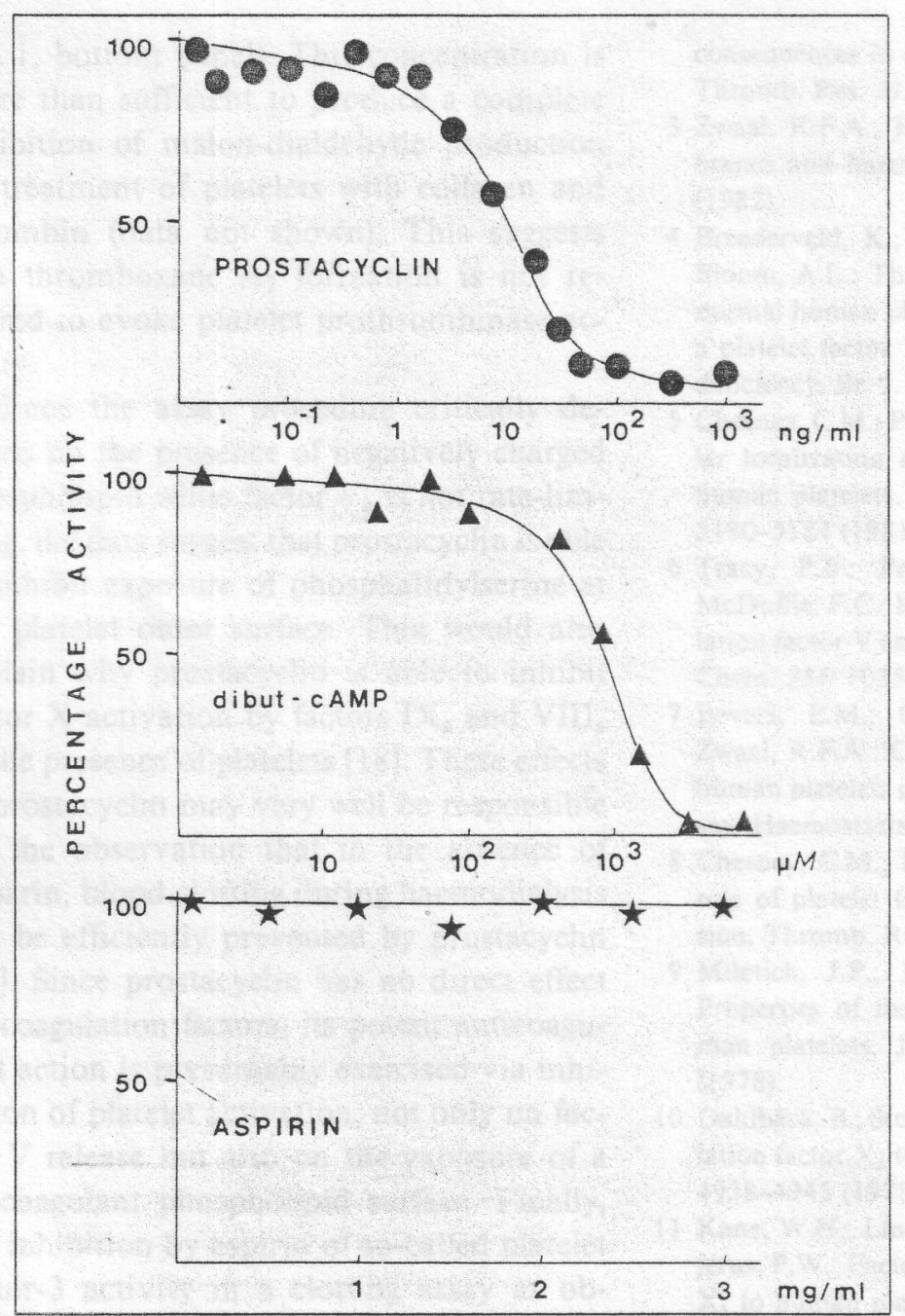

Fig. 1. Platelet prothrombinase activity generated by treatment with collagen plus thrombin in the presence of prostacyclin, dibutyryl CAMP or aspirin. Activity is expressed as percentage of activity observed in the absence of inhibitors.
$10 \mathrm{ng} / \mathrm{ml}$. This is approximately 3 times higher than required to produce half-maximal inhibition of platelet aggregation and release (data not shown), and of the same order as required to inhibit platelet adhesion to collagen [20]. No inhibition was observed when prostacyclin was added after the activation procedure. The inhibitory activity of prostacyclin might be related to its ability to increase cyclic AMP concentrations in platelets
[17]. Treatment of platelets with dibutyrylcAMP also produces dose-related inhibition of platelet prothrombinase activity, being half-maximal at $800 \mu M$ (fig. 1, middle panel). In order to check if the inhibitory effect of prostacyclin would depend on decreased thromboxane $A_{2}$ production of the platelets, the effect of aspirin was also measured. Aspirin up to $3 \mathrm{mg} / \mathrm{ml}$ was completely unable to inhibit platelet prothrombinase activity 
(fig. 1, bottom panel). This concentration is more than sufficient to produce a complete inhibition of malon-dialdehyde production by treatment of platelets with collagen and thrombin (data not shown). This suggests that thromboxane $A_{2}$ formation is not required to evoke platelet prothrombinase activity.

Since the assay procedure critically depends on the presence of negatively charged phospholipid while factor $V_{a}$ is not rate-limiting, the data suggest that prostacyclin is able to inhibit exposure of phosphatidylserine at the platelet outer surface. This would also explain why prostacyclin is able to inhibit factor $\mathrm{X}$ activation by factors $\mathrm{IX}_{\mathrm{a}}$ and $\mathrm{VIII}_{\mathrm{a}}$ in the presence of platelets [18]. These effects of prostacyclin may very well be responsible for the observation that in the absence of heparin, blood clotting during haemodialysis can be efficiently prevented by prostacyclin [19]. Since prostacyclin has no direct effect on coagulation factors, its potent anticoagulant action is presumably exercised via inhibition of platelet activation, not only on factor $\mathrm{V}$ release but also on the exposure of a procoagulant phospholipid surface. Finally, the inhibition by aspirin of so-called platelet factor-3 activity in a clotting assay as observed by others [2], is presumably caused only by inhibition of release of factor $V$ from platelets, rather than by inhibiting exposure of procoagulant phospholipids.

\section{References}

1 Ts'ao, C-H.; Holly, C.M.; Serieno, M.A.; Galluzzo, T.S.: Generation of a $\mathrm{PGI}_{2}$-like activity by deendothelialized rat aorta. Thrombos. Haemostasis 42: 873-884 (1979).

2 Bunting, S.; Simmons, P.M.; Moncada, S.: Inhibition of platelet activation by prostacyclin: possible consequences in coagulation and anticoagulation. Thromb. Res. 21: 89-102 (1981).

3 Zwaal, R.F.A.; Hemker, H.C.: Blood cell membranes and haemostasis. Haemostasis 11: 12-39 (1982).

4 Breederveld, K.; Giddings, J.C.; ten Cate, J.W.; Bloom, A.L.: The localization of factor $\mathrm{V}$ within normal human platelets and the demonstration of a platelet factor $\mathrm{V}$ antigen in congenital factor $\mathrm{V}$ deficiency. Br. J. Haemat. 29: 405-412 (1975).

5 Chesney, C.M.; Pifer, D.; Colman, R.W.: Subcellular localization and secretion of factor $\mathrm{V}$ from human platelets. Proc. natn. Acad. Sci. USA 78: 5180-5184 (1981).

6 Tracy, P.B.: Peterson, J.M.; Nesheim, M.E.; McDuffie, F.C.; Mann, K.G.: Interaction of coagulation factor $\mathrm{V}$ and factor $\mathrm{V}_{\mathrm{a}}$ with platelets. J. biol. Chem. 254: 10354-10361 (1979).

7 Bevers, E.M.; Comfurius, P.; Hemker, H.C.; Zwaal, R.F.A.: On the clot-promoting activity of human platelets in a one-stage prothrombinase assay. Haemostasis 12: 268-274 (1982).

8 Chesney, C.M.; Pifer, D.D.; Colman, R.W.: The role of platelet factor $\mathrm{V}$ in prothrombin conversion. Thromb. Res. 29: 75-84 (1983).

9 Miletich, J.P.; Jackson, C.M.; Majerus, P.W.: Properties of the factor $X_{a}$ binding site on human platelets. J. biol. Chem. 253: 6908-6916 (1978).

10 Dahlbäck, B.; Stenflo, J.: Binding of bovine coagulation factor $\mathrm{X}_{\mathrm{a}}$ to platelet. Biochemistry, N.Y. 17: 4938-4945 (1978).

11 Kane, W.H.; Lindhout, M.J.; Jackson, C.M.; Majerus, P.W.: Factor $\mathrm{V}_{\mathrm{a}}$ dependent binding of factor $\mathrm{X}_{\mathrm{a}}$ to human platelets. J. biol. Chem. 255: 11701174 (1980).

12 Bevers, E.M.; Comfurius, P.; van Rijn, J.L.M.L.; Hemker, H.C.; Zwal, R.F.A.: Generation of prothrombin converting activity and the exposure of phosphatidylserine at the outer surface of platelets. Eur. J. Biochem. 122: 429-436 (1982).

13 Bevers, E.M.; Comfurius, P.; Zwaal, R.F.A.: Changes in membrane phospholipid distribution during platelet activation. Biochim. biophys. Acta 736: 57-66 (1983).

14 Macintyre, D.E.: Modulation of platelet function by prostaglandins: characterization of platelet receptors for stimulatory prostaglandins and the role of arachidonate metabolites in platelet degranulation responses. Haemostasis 8: 274-293 (1979). 
15 Rosing, J.; Tans, G.; Govers-Riemslag, J.W.P.; Zwaal, R.F.A.; Hemker, H.C.: The role of phospholipids and factor $\mathrm{V}_{\mathrm{a}}$ in the prothrombinase complex. J. biol. Chem. 255: 274-283 (1980).

16 Feinman, R.D.; Lubowsky, J.; Charo, I.; Zabinski, M.P.: The lumi-aggregometer: a new instrument for simultaneous measurement of secretion and aggregation by platelets. J. Lab. clin. Med. 90:125129 (1977).

17 Tateson, J.E.; Moncada, S.; Vane, J.R.: Effects of prostacyclin on cyclic AMP concentrations in human platelets. Prostaglandins 13: 389-397 (1977).

18 Hornstra, G.: Platelet-vessel wall interaction: role of blood clotting. Phil. Trans. R. Soc. 294: 355371 (1981).

19 Woods, H.F.; Ash, G.; Weston, M.J.; Bunting, S.; Moncada, S.; Vane, J.R.: Prostacyclin can replace heparin in haemodialysis in dogs. Lancet ii: 10751077 (1978).
20 Karniguian, A.; Simmons, P.; Legrand, Y.J.; Moncada, S.; Caen, J.: A comparison of the inhibitory effects of prostacyclin and carbacyclin on platelet adhesion to collagen. Prostaglandins 24: 827-836 (1982).

Received: April 6, 1984

Accepted in revised form by editor J. Caen: May 16, 1984

R.F.A. Zwaal,

Biomedical Centre,

University of Limburg,

P.O. Box 616,

6200 MD Maastricht (The Netherlands) 